\title{
Perbedaan Metode Pembelajaran Kooperatif Tipe Jigsaw dan Konvensional terhadap Prestasi Belajar Mahasiswa
}

\author{
Suwarno $^{1 *}$ \\ ${ }^{1}$ Universitas Muhammadiyah Gresik
}

\begin{abstract}
One of the factors that affect student achievement is a learning model. Conventional learning models provide a low success rate compared with the cooperative model. Conventional learning model gives a major role to the faculty and students tend to be passive. While the cooperative learning model provides the opportunity for students to learn actively and teachers act as facilitators. One model is a model of cooperative learning jigsaw. Jigsaw model study is a model of learning in groups in which each individual is required to play an active role in contributing to the group. The sample was accounting students who take the course of financial accounting. Results of testing using t test showed that there are significant differences between conventional teaching with the type of jigsaw. The average student results showed that the average achievement of student learning is better than the conventional type of cooperative learning jigsaw.
\end{abstract}

Keywords: Achievement, conventional learning, and Jigsaw.

Tipe artikel: Empiris

\section{Pendahuluan}

\subsection{Latar Belakang Masalah}

Perguruan tinggi merupakan ujung tombak daya saing bangsa. Karena perguruan tinggi adalah tempat untuk mendidik anak bangsa menjadi sumber daya manusia yang unggul. Sumber daya manusia yang unggul diharapkan mampu bersaing di kancah persaingan global. Sehingga pendidikan tinggi ikut serta memberikan kontribusi dalam memajukan suatu bangsa melalui sistem pendidikan yang berkualitas. Sistem pendidikan tinggi yang berkualitas adalah sistem yang mampu menghasilkan sarjana yang bermutu.

Sistem pendidikan di suatu perguruan tinggi dirancang untuk menghasilkan lulusan yang bermutu. Sarjana yang bermutu adalah sarjana dengan kompetensi serta kualifikasi yang dapat memenuhi kebutuhan pasar. Sehingga menjadi kewajiban pemerintah untuk menyusun regulasi sistem pendidikan di Indonesia agar menghasilkan sumber daya manusia yang mampu bersaing dengan negara-negara maju. Sehingga tidak heran jika pemerintah selalu melakukan evaluasi terhadap sistem pendidikan dalam setiap periode tertentu. Terakhir pemerintah dalam hal ini Direktorat Pendidikan Tinggi (DIKTI) mulai menerapkan sistem pendidikan tinggi yang dinamakan dengan Kerangka Kualifikasi Nasional

\footnotetext{
${ }^{*}$ Penulis yang sesuai:

E-mail: suwarno@umg.ac.id

Afiliasi: Universitas Muhammadiyah Gresik
} 
Indonesia (KKNI). KKNI dirancang untuk memberikan standar kualifikasi lulusan sesuai dengan jenjang pendidikan akhir yang telah ditempuh.

KKNI pada hakekatnya untuk meningkatkan mutu lulusan. Sedangkan mutu lulusan sangat berhubungan dengan proses pendidikan yang terjadi pada pendidikan tinggi. Proses pendidikan adalah kegiatan memobilisasi segenap sumber daya pendidikan untuk mencapai tujuan pendidikan. Maka perguruan tinggi perlu untuk menyusun sistem akademik seperti kurikulum, pengajaran, dan perangkat lain untuk mencapai tujuan pendidikan. Kurikulum dan isi mata kuliah dirancang sedemikian rupa sehingga sesuai dengan tuntutan dari pengguna lulusan atau kebutuhan pasar.

Selain kurikulum, faktor yang penting untuk meningkatkan mutu lulusan adalah kegiatan pembelajaran. Kegiatan pembelajaran adalah kegiatan yang dilakukan oleh guru sedemikian rupa, sehingga tingkah laku mahasiswa berubah ke arah yang lebih baik. Pembelajaran bertujuan membantu mahasiswa agar memperoleh berbagai pengalaman dan dengan pengalaman itu tingkah laku mahasiswa yang meliputi pengetahuan, keterampilan, dan nilai atau norma yang berfungsi sebagai pengendali sikap dan perilaku mahasiswa menjadi bertambah, baik kuantitas maupun kualitasnya (Andrean, 2013).

Salah faktor keberhasilan kegiatan pembelajaran adalah cara atau model pembelajaran yang diterapkan. Kegiatan pembelajaran dengan cara konvensional sudah mulai ditinggalkan. Kegiatan pembelajaran konvensional adalah pembelajaran dengan cara melakukan tatap muka di kelas, menyelesaikan soal dan tugas mandiri (Purwanti dan Ismail, 2011). Kegiatan pembelajaran seperti ini menfokuskan dosen sebagai subjek yang aktif dan mahasiswa sebagai objek yang pasif. Kegiatan pembelajaran seharusnya memberikan ruang atau menfokuskan kepada mahasiswa untuk terlibat secara aktif dan dosen bertugas sebagai fasilitator.

Dalam model konvensional, pengajar memegang peranan utama dalam menentukan isi dan urutan langkah dalam menyampaikan materi tersebut kepada peserta didik. Sementara peserta didik mendengarkan secara teliti serta mencatat pokok-pokok penting yang dikemukakan pengajar sehingga pada pembelajaran ini kegiatan proses belajar mengajar didominasi oleh pengajar. Hal ini mengakibatkan peserta bersifat pasif, karena peserta didik hanya menerima apa yang disampaikan oleh pengajar, akibatnya peserta didik mudah jenuh, kurang inisiatif, dan bergantung pada pengajar (Jainuri, 2010.).

Kelemahan kegiatan pembelajaran konvensional tersebut telah mendorong banyak pihak untuk melakukan perubahan-perubahan model pembelajaran yang lebih kooperatif. Salah satu model pembelajaran kooperatif adalah model pembelajaran jigsaw. Teknik mengajar jigsaw dikembangkan dan diuji oleh Elliot Arronson dan rekan-rekannya di Universitas Texas, dan kemudian diadaptasi oleh Slavin dan kawan-kawan di Universitas John Hopkin (Sugianto, 2010:45).

Model pembelajaran jigsaw merupakan salah satu variasi model collaborative learning yaitu proses belajar kelompok dimana setiap anggota menyumbangkan informasi, pengalaman, ide, sikap, pendapat, kemampuan, dan keterampilan yang dimilikinya, untuk secara bersama-sama saling meningkatkan pemahaman seluruh anggota. Pembelajaran kooperatif tipe jigsaw adalah suatu tipe pembelajaran kooperatif yang terdiri dari beberapa anggota dalam satu kelompok yang bertanggung jawab atas penguasaan bagian materi belajar dan mampu mengajarkan materi tersebut kepada anggota lain dalam kelompoknya (Sudrajat, 2008).

Prestasi mahasiswa diharapkan akan meningkatkan seiring dengan perubahan model pembelajaran konvensional ke model kooperatif tipe jigsaw. Karena mahasiswa diberikan ruang secara aktif untuk berpartisipasi dalam proses pembelajaran sehingga peran dosen tidak sekedar mentransfer ilmu tetapi mengajarkan kepada mahasiswa untuk bekerja sama serta memberikan kesempatan kepada mahasiswa untuk mengolah

\subsection{Rumusan Masalah}

Berdasarkan latar belakang dan permasalahan di atas, maka rumusan masalah dalam penelitian ini adalah apakah terdapat perbedaan pembelajaran koorperatif model jigsaw dan pembelajaran konvensional terhadap prestasi belajar mahasiswa.

\section{Tinjuan Pustaka}

\subsection{Pembelajaran Kooperatif}


Pembelajaran kooperatif (cooperatiflearning) merupakan bentuk pembelajaran dengan cara mahasiswa belajar dan bekerja dalam kelompok-kelompok kecil secara kolaborasi yang anggotanya terdiri empat sampai enam orang dengan struktur kelompok yang bersifat heterogen. Dalam pembelajaran ini tercipta sebuah interaksi yang lebih luas yaitu interaksi dan komunikasi yang dilakukan antara dosen dengan mahasiswa, dan mahasiswa dengan dosen (Rusman, 2011).

Menurut Siahaan (dalam Rusman, 2011) bahwa ada lima unsur penting yang ditekankan dalam pembelajaran kooperatif yaitu (a) saling ketergantungan yang positif, artinya dalam pembelajaran kooperatif, keberhasilan dalam penyelesaian tugas tergantung pada usaha yang dilakukan oleh kelompok tersebut. Keberhasilan kerja kelompok ditentukan oleh kinerja masing-masing anggota kelompok. Oleh karena itu, semua anggota dalam kelompok akan merasakan saling ketergantungan, (b) tanggung jawab perorangan, artinya karena keberhasilan kelompok sangat tergantung dari masingmasing anggota kelompoknya maka setiap anggota kelompok mempunyai tugas dan tanggung jawab yang harus dikerjakan dalam kelompok tersebut, (c) interaksi tatap muka, yaitu memberikan kesempatan yang luas kepada setiap anggota kelompok untuk tatap muka melakukan interaksi dan diskusi untuk saling memberi dan menerima informasi dari kelompok lain, (d) partisipasi dan komunikasi yaitu melatih mahasiswa untuk mendapat berpartisipasi aktif dan berkomunikasi dalam kegiatan pembelajaran, dan (e) evaluasi proses kelompok yaitu menjadwalkan waktu khusus bagi kelompok untuk mengevaluasi proses kerja kelompok dan hasil kerja sama mereka, agar selanjutnya bisa bekerja sama dengan lebih efektif.

Menurut Rusman (2011) pembelajaran kooperatif mempunyai karakteristik antara lain:

a. Pembelajaran secara tim, yaitu pembelajaran kooperatif adalah pembelajaran dilakukan secara tim.

Tim merupakan tempat untuk mencapai tujuan dan harus mampu membuat setiap mahasiswa belajar;

b. Didasarkan pada manajemen kooperatif, yaitu pembelajaran kooperatif dilaksanakan dengan memperhatikan fungsi-fungsi manajemen antara dilakukan dengan perencanaan, diorganisasikan dan di kontrol oleh dosen;

c. Kemauan untuk bekerja sama, yaitu keberhasilan pembelajaran kooperatif ditentukan oleh keberhasilan secara kelompok, oleh karenannya prinsip kebersamaan atau kerja sama perlu ditekankan dalam pembelajaran kooperatif;

d. Ketrampilan bekerja sama, yaitu kemampuan bekerja sama itu dipraktekkan melalui aktivitas dalam kegiatan pembelajaran secara berkelompok.

Menurut Slavin (dalam Purwanti dan Ismail, 2011) bahwa keberhasilan cooperatif learning ditentukan pada dua aspek yaitu teori motivasi dan kognitif. Menurut teori motivasi, motivasi mahasiswa dalam pembelajaran kooperatif terutama terletak dalam bagaimana bentuk hadiah atau struktur pencapaian tujuan saat mahasiswa melaksanakan kegiatan. Diidentifikasi ada tiga macam struktur pencapaian tujuan yaitu (a). kooperatif di mana orientasi tujuan masing-masing mahasiswa turut membantu pencapaian tujuan mahasiswa lain, (b). kompetitif di mana upaya mahasiswa untuk mencapai tujuan akan menghalangi mahasiswa lain dalam pencapaian tujuan, dan (c). individualistik di mana upaya mahasiswa untuk mencapai tujuan tidak ada hubungannya dengan mahasiswa lain dalam mencapai tujuan tersebut.

Sedangkan teori kognitif mengukur efek-efek dari bekerja sama dalam diri individu. Teori ini dikelompokkan ke dalam dua kategori yaitu (a). teori perkembangan: asumsi dasar teori perkembangan adalah interaksi mahasiswa di antara tugas-tugas yang sesuai meningkatkan penguasaan mereka terhadap konsep-konsep yang sulit, dan (b). teori elaborasi kognitif memiliki pandangan yang berbeda. Penelitian dalam penelitian psikologi kognitif telah menemukan bahwa supaya informasi dapat disimpan di dalam memori dan terkait dengan informasi yang sudah ada dalam memori itu, maka mahasiswa harus terlibat dalam kegiatan restruktur atau elaborasi kognitif materi.

Menurut Rusman $(2011,213)$ prosedur pembelajaran kooperatif pada prinsipnya terdiri atas empat tahap, yaitu:

a. Penjelasan materi, tahap ini merupakan tahapan penyampaian pokok-pokok materi pelajaran sebelum mahasiswa belajar dalam kelompok;

b. Belajar kelompok, tahapan ini dilakukan setelah dosen memberikan penjelasan materi, mahasiswa bekerja dalam kelompok yang telah dibentuk sebelumnya; 
c. Penilaian, penilaian dalam pembelajaran kooperatif bisa dilakukan melalui tes atau kuis, yang dilakukan secara individu atau kelompok. Tes individu akan memberikan penilaian kemampuan individu, sedangkan kelompok akan memberikan penilaian pada kemampuan kelompoknya;

d. Pengakuan tim, adalah penetapan tim yang paling dianggap menonjol atau tim paling berprestasi untuk kemudian diberikan penghargaan atau hadiah, dengan harapan dapat memotivasi tim untuk terus berprestasi lebih baik lagi.

\subsection{Model Pembelajaran Jigsaw}

Salah satu model pembelajaran kooperatif yang sudah lama dikembangkan oleh Elliot Aronson dan teman-temannya dari Universitas Texas dinamakan dengan Jigsaw. Jigsaw berasal dari bahasa Inggris yang bermakna gergaji ukir atau puzzle. Pembelajaran kooperatif model jigsaw ini mengambil pola cara bekerja sebuah gergaji (zigzag), yaitu mahasiswa melakukan kegiatan belajar dengan cara bekerja sama dengan mahasiswa lain untuk mencapai tujuan (Rusman, 2011).

Model pembelajaran kooperatif model ini lebih menitikberatkan pada kerja sama dalam kelompokkelompok kecil dalam ruangan kelas. Kerja sama dalam kelompok ataupun antar kelompok dalam kelas akan memberikan keuntungan antara lain memacu mahasiswa untuk lebih aktif, kreatif serta bertanggung jawab terhadap proses belajarnya, mendorong mahasiswa untuk berpikir kritis, memberi kesempatan setiap mahasiswa untuk menerapkan ide yang dimiliki untuk menjelaskan materi yang dipelajari kepada mahasiswa lain dalam kelompok tersebut, dan diskusi tidak didominasi oleh mahasiswa tertentu saja tetapi semua mahasiswa dituntut untuk menjadi aktif dalam diskusi tersebut (http://dasar-teori.blogspot.com)

Pembelajaran kooperatif model jigsaw memberikan kesempatan kepada mahasiswa untuk mengolah informasi dan mengkomunikasikannya. Sehingga mahasiswa selain mendapat ilmu juga dapat meningkatkan ketrampilan dalam berkomunikasi dan bekerja sama dalam sebuah kelompok. Berikut adalah langkah-langkah pembelajaran model jigsaw:

a. Dosen membagi mahasiswa satu kelas menjadi kelompok kecil. Setiap kelompok terdapat 1 mahasiswa sebagai ketua kelompok. Kelompok ini disebut kelompok asal.

b. Setiap ketua kelompok dalam kelompok asal berkumpul dalam satu kelompok yang disebut dengan kelompok ahli.

c. Anggota kelompok ahli berdiskusi dengan cara bergantian mempresentasikan tugas masing-masing sampai setiap kelompok ahli semua tugas didiskusikan.

d. Setiap anggota kelompok ahli kembali ke kelompok asal untuk menyampaikan hasil diskusi di kelompok ahli.

e. Masing-masing kelompok asal presentasi menyampaikan hasil diskusi sesuai dengan tugas masingmasing. Presentasi dapat dilakukan secara bergantian untuk setiap anggota kelompok asal.

f. Dosen memberikan penghargaan pada kelompok melalui skor penghargaan berdasarkan kemampuan prestasi. (Arends:1994)

Lie (dalam Rusman, 2011) menyatakan bahwa Jigsaw merupakan salah satu tipe atau model pembelajaran kooperatif yang paling fleksibel. Banyak riset yang telah dilakukan terkait dengan pembelajaran kooperatif model Jigsaw. Riset tersebut secara konsisten menunjukkan bahwa mahasiswa yang terlibat dalam memperoleh prestasi lebih baik, mempunyai sikap yang lebih baik dan lebih positif terhadap pembelajaran, di samping saling menghargai perbedaan dan pendapat orang lain. Salah satu hasil riset yang dilakukan oleh Purwanti dan Ismail (2011) adalah terdapat perbedaan yang signifikan prestasi belajar mahasiswa pada mata kuliah akuntansi keuangan menengah I dengan topik IFRS antara metode konvensional dan jigsaw. Metode pembelajaran jigsaw terbukti lebih efektif daripada metode konvensional karena mampu mengarahkan mahasiswa untuk aktif berinovasi dalam memahami materi yang diajarkan, meningkatkan rasa tanggung jawab dan meningkatkan prestasi belajar.

\section{Metode Penelitian}

Metode penelitian yang digunakan dalam penelitian ini adalah metode eksperimen semu. Penelitian eksperimen adalah kegiatan percobaan (experiment), yang bertujuan untuk mengetahui suatu gejala atau pengaruh yang timbul, sebagai akibat dari adanya perlakuan tertentu. Eksperimen semu digunakan 
karena tidak memungkinkan untuk mengontrol semua variabel yang mempengaruhi prestasi hasil belajar mahasiswa (Purwanti dan Ismail, 2011).

Adapun langkah-langkah penelitian dengan metode eksperimen semu secara umum adalah sebagai berikut :

1. Melakukan kajian induktif terkait dengan permasalahan yang akan diteliti.

2. Mengidentifikasi dan mendefinisikan masalah.

3. Melakukan studi literatur dan sumber-sumber yang relevan, memformulasikan hipotesis, merumuskan definisi operasional.

4. Menyusun rencana penelitian.

5. Melakukan eksperimen

6. Mengumpulkan data kasar dan proses eksperimen.

7. Mengorganisasikan dan mendeskripsikan data sesuai dengan variabel.

8. Menganalisis data dan melakukan test signifikan dengan teknik statistik yang relevan untuk menentukan tahap signifikansi hasil.

9. Menginterprestasikan hasil, perumusan kesimpulan, pembahasan dan pembuatan laporan. (Sukardi, 2003)

Subjek penelitian adalah mahasiswa jurusan akuntansi Universitas Muhammadiyah Gresik yang sedang menempuh mata kuliah isu-isu akuntansi kontemporer. Alasannya dipilih subjek tersebut karena mahasiswa akuntansi yang akan menempuh mata kuliah isu kontemporer akuntansi telah menempuh materi akuntansi keuangan menengah pada semester 3 .

Pengamatan akan dilakukan terhadap dua kelompok yaitu satu kelompok treatment dan kelompok kontrol. Kelompok treatment adalah mahasiswa semester IV kelas pagi yang sedang menempuh matakuliah isu-isu akuntansi kontemporer dengan metode pembelajaran Jigsaw (Treatment). Sedangkan mahasiswa semester IV kelas sore adalah kelompok kontrol dengan metode pembelajaran konvensional (tidak treatment).

Variabel penelitian adalah prestasi belajar mahasiswa. Prestasi belajar mahasiswa adalah ukuran keberhasilan kegiatan belajar mahasiswa dalam menguasai sejumlah mata kuliah selama periode tertentu yang dinyatakan dalam bentuk angka atau huruf (Azharm, 2012). Pengukuran variabel prestasi mahasiswa mengunakan nilai berupa angka yang diperoleh hasil post-test atas dua capaian pembelajaran khusus.

Hasil dari post-test selanjutnya akan dilakukan pengujian data. Pengujian data akan mengunakan analisis statistik diskriptif (mean, standar deviasi, min dan max), uji normalitas data, uji kesamaan varian, dan uji beda rata-rata. Uji beda rata-rata bertujuan untuk menguji apakah ada perbedaan ratarata secara signifikan antara kedua kelompok. Adapun kriteria pengujian adalah sebegai berikut :

$\mathrm{H}_{0} ; \mu_{1}=\mu_{2}$ artinya $\mathrm{H}_{0}$ diterima dan $\mathrm{H}_{\mathrm{a}}$ ditolak. Hal ini berarti tidak ada perbedaan yang signifikan antara kedua kelompok.

$\mathrm{H}_{\mathrm{a} ;} \quad \mu_{1} \neq \mu_{2}$ artinya $\mathrm{H}_{0}$ ditolak dan $\mathrm{H}_{\mathrm{a}}$ diterima. Hal ini berarti ada perbedaan yang signifikan antara kedua kelompok

\section{Hasil Penelitian}

\subsection{Statistik Diskriptif}

Kelas yang menjadi sampel penelitian atau eksperimen adalah kelas semester IV (empat) yaitu mata kuliah akuntansi keuangan II pada tahun akademik 2014 dan 2015 dengan metode pembelajaran kooperatif tipe jigsaw. Sedangkan data untuk pembelajaran konvensional menggunakan hasil pembelajaran pada mata kuliah akuntansi keuangan I. Tabel 4.1 di bawah ini menunjukkan deskripsi statistik (Mean, standar deviasi) hasil pembelajaran kedua metode.

Tabel 4.1

Diskripsi Statistik IPK

\begin{tabular}{|l|l|r|r|r|r|}
\hline & Metode & N & Mean & \multicolumn{1}{|c|}{$\begin{array}{c}\text { Std. } \\
\text { Deviation }\end{array}$} & $\begin{array}{c}\text { Std. Error } \\
\text { Mean }\end{array}$ \\
\hline \multirow{2}{*}{ IPK } & Konvension & 71 & 59,0141 & 10,02211 & 1,18941 \\
\cline { 2 - 6 } & Jigshow & 71 & 54,6901 & 7,56041 &, 89726 \\
\hline
\end{tabular}


Berdasarkan tabel 4.1 menunjukkan bahwa nilai rata-rata (mean) dari hasil belajar kelas ekperimen 54,69 sedangkan kelas kontrol 59,01. Maka dapat disimpulkan bahwa rata-rata hasil belajar kelas kontrol lebih tinggi dibanding dengan kelas ekperimen. Kalau diamati lebih jauh dengan menggunakan tabel 4.2 (Frekuensi hasil belajar kelas kontrol) maka dapat dilihat dari penyebaran nilai yang besar prosentasenya yaitu nilai $\mathrm{C}$ sebesar $30 \%$ dan kedua adalah nilai $\mathrm{BC}$ sebesar $16 \%$.

Tabel 4.2

Frekuensi hasil belajar kelas kontrol

\begin{tabular}{|c|c|c|c|c|c|}
\hline \multicolumn{2}{|c|}{} & Frequency & Percent & $\begin{array}{c}\text { Valid } \\
\text { Percent }\end{array}$ & $\begin{array}{c}\text { Cumulative } \\
\text { Percent }\end{array}$ \\
\hline \multirow{5}{*}{ Valid } & A & 1 & 1,4 & 1,4 & 1,4 \\
\cline { 2 - 6 } & AB & 6 & 8,5 & 8,5 & 9,9 \\
\cline { 2 - 6 } & B & 8 & 11,3 & 11,3 & 21,1 \\
\cline { 2 - 6 } & BC & 16 & 22,5 & 22,5 & 43,7 \\
\cline { 2 - 6 } & C & 30 & 42,3 & 42,3 & 85,9 \\
\cline { 2 - 6 } & D & 10 & 14,1 & 14,1 & 100,0 \\
\cline { 2 - 6 } & Total & 71 & 100,0 & 100,0 & \\
\hline
\end{tabular}

Sedangkan penyebaran hasil belajar dari kelas eksperimen adalah nilai C sebesar 36\%, nilai D sebesar $21 \%$, nilai BC sebesar 9\% dan nilai B sebesar $5 \%$.

Tabel 4.3

Frekuensi hasil belajar kelas eksperimen

\begin{tabular}{|c|c|c|c|c|c|}
\hline \multicolumn{2}{|c|}{} & Frequency & Percent & $\begin{array}{c}\text { Valid } \\
\text { Percent }\end{array}$ & $\begin{array}{c}\text { Cumulative } \\
\text { Percent }\end{array}$ \\
\hline \multirow{4}{*}{ Valid } & B & 5 & 7,0 & 7,0 & 7,0 \\
\cline { 2 - 6 } & BC & 9 & 12,7 & 12,7 & 19,7 \\
\cline { 2 - 6 } & C & 36 & 50,7 & 50,7 & 70,4 \\
\cline { 2 - 6 } & D & 21 & 29,6 & 29,6 & 100,0 \\
\cline { 2 - 6 } & Total & 71 & 100,0 & 100,0 & \\
\hline
\end{tabular}

Jika kita bandingkan hasil belajar dari kedua kelompok kontrol dan eksperimen berdasarkan penyebaran nilai, maka kelas kontrol lebih bervariasi daripada kelompok ekperimen.

\subsection{Analisis Uji Beda Rata-Rata}

Uji beda rata-rata digunakan untuk menguji apakah terdapat perbedaan rata-rata antara kelas ekperimen (kelas dengan pembelajaran type jigshaw) dengan kelas kontrol (kelas dengan pembelajaran konvensional). Pengujian dilakukan dengan mengunakan uji t (t-test) dengan kriteria pengujian jika nilai probabilitas lebih besar dari 5\% atau nilai t hitung lebih besar dari t tabel, maka dapat disimpulkan bahwa terdapat perbedaan dan signifikan antara kedua kelompok.

Pengujian dilakukan dengan dua tahapan, tahap pertama adalah pengujian terhadap kesamaan varian dan dilanjutkan pengujian tahap kedua yaitu uji t. Pengujian terhadap kesamaan varian, menurut Singgih Santoso $(2010 ; 269)$ jika nilai signifikansinya $>5 \%$, maka kedua varian dinyatakan sama. Hasil pengujian sebagaimana nampak pada tabel 4.4 menunjukkan nilai signifikansi 0,15 >0,05. Sehingga dapat disimpulkan bahwa terdapat kesamaan varian dari kedua kelompok. Sedangkan hasil uji t pada tabel 4.4 menunjukkan nilai probabilitas hasil belajar pada kolom equal variance assumed sebesar 0,004 $<0,05$. Maka dapat disimpulkan terhadap perbedaan rata-rata antara kedua kelompok.

Kesimpulan hasil uji dengan menggunakan $\mathrm{t}$ test adalah terdapat kesamaan varian antara kedua kelas atau $\mathrm{H}_{0}$ di tolak dan $\mathrm{H}_{1}$ diterima, artinya terhadap perbedaan terhadap hasil belajar dari kedua kelompok.

\subsection{Interprestasi Hasil.}


Berdasarkan hasil belajar mahasiswa menggunakan pembelajaran kooperatif tipe jigsaw, menunjukkan bahwa rata-rata hasil belajar mahasiswa adalah 54,6 dan prosentase mahasiswa yang mendapatkan nilai D $(29,6 \%)$. Sedangkan hasil pembelajaran konvensional menunjukkan bahwa rata-rata hasil belajar mahasiswa sebesar 59,01 dan prosentase mahasiswa yang mendapatkan nilai D (14,1\%). Hal ini menunjukkan bahwa hasil pembelajaran konvensional dapat disimpulkan memberikan hasil yang lebih baik daripada pembelajaran kooperatif tipe jigsaw.

Pembelajaran kooperatif tipe jigsaw memerlukan kesiapan dosen dan mahasiswa, latar belakang mahasiswa serta waktu pembelajaran yang diperlukan cukup lama. Mahasiswa perlu memahami materi perkuliahan sebelum pelaksanaan pembelajaran. Selain itu, waktu yang diperlukan untuk kegiatan pembelajaran cukup lama karena tahapan kegiatan pembelajaran yang perlu dilalukan dalam diskusi tersebut (Mawardi dan Prihati, 2011).

Pembelajaran kooperatif jigsaw memerlukan kerja sama kelompok. sehingga kerja sama kelompok yang kurang akan mempengaruhi hasil pembelajaran. Faktor lain yang mempengaruhi adalah materi pembelajaran. Mata kuliah akuntansi keuangan sebagian merupakan materi perhitungan angkaangka akuntansi dan hanya sedikit materi konseptual, sehingga materi kurang menarik untuk di diskusikan.

Sarana dan prasarana pendukung sangat mempengaruhi dalam keberhasilan pembelajaran kooperatif. Tata letak kursi sangat penting dalam berdiskusi kelompok seperti tata letak kursi yang berbentuk melingkar akan sangat membantu dalam berinteraksi dan berkomunikasi sesama mahasiswa dalam kelompok maupun dengan kelompok lain.

\section{Simpulan dan Saran}

Berdasarkan hasil pembahasan diatas, maka kesimpulan dalam penelitian ini antara lain :

1. Terdapat perbedaan yang signifikan antara pembelajaran konvensional dengan pembelajaran kooperatif tipe jigsaw terhadap prestasi belajar mahasiswa pada mata kuliah akuntansi keuangan.

2. Rata-rata prestasi mahasiswa dengan pembelajaran konvensional lebih baik dibanding dengan pembelajaran kooperatif tipe jigsaw.

\section{Daftar Pustaka}

Andrean, 2013. Pengertian Belajar, Mengajar, Pembelajaran, http://www.andreanperdana.com, diakses tanggal 12 Februari 2015 jam 6.56

Azharm, 2012. Definis pengertian dan faktor-faktor yang mempengaruhi prestasi belajar http://azharm2k.wordpress.com, diakses tanggal 12 Februari 2015 jam 16.23

Anonim, 2011. Kelebihan dan kekurangan pembelajaran, http://dasar-teori.blogspot.com, diakses tanggal 3 Februari 2015 jam 8.43

Jainuri, 2010. Pembelajaran Konvensional, http://www.academia.edu, diakses tanggal 12 Februari 0215 jam 8.44

Jurusan Akuntansi FE Univ. Brawijaya, Malang

Mawardi dan Prihatini, 2011. Perbedaan Efektfitas Pembelajaran Kooperatif Tipe Jigsaw dan Konvensional pada Mata Pelajaran PKn kelas IV SD Negeri Badran Kecamatan Kargan Tulungagung, Jurnal Solaria, Vol. 1, Hal. 194-238

Purwanti dan Islamil, 2011. Pengaruh Metode Pembelajaran Kooperatif Tipe Jigsaw Terhadap Prestasi Mahasiswa: Sebuah Eksperimen Semu, Jurnal Akuntansi Multiparadigma, Vol.2, No.3 Desember,

Sugianto, 2010. Model-model Pembelajaran Inovatif, Surakarta: Yuma Pustaka

Sudrajat dan Akhmad, 2008. Cooperative Learning-teknik Jigsaw. http://akhmadsudrajat.wordpress.com, diakses tanggal 12 Februari 2015. 